\title{
Governing the Circular Economy in the City: Local Planning Practice in London
}

Catalina Turcu catalina.turcu@ucl.ac.uk (corresponding author)

and

Hannah Gillie hgillie@ outlook.com

Bartlett School of Planning

University College London

UK

$* * *$

Accepted Dec 2019. To quote please use:

Turcu \& Gillie (2020) Governing the Circular Economy in the City: Local Planning Practice in London, Planning Practice \& Research 


\begin{abstract}
There is currently much interest in the circular economy as a framework for transition from a linear take-make-dispose model of production and consumption, to a circular model which decouples economic growth from environmental degradation and natural resource consumption. However, there is limited understanding of how this applies to a city context, especially from a spatial perspective and taking into account the multitude of urban governance arrangements at various levels. In this paper we examine evidence from 28 (out of 32) planning authorities in London to understand what government for the circular economy of London exists and how governance shapes it at the local level. We discuss current planning tools and uncover the intricate politics of intra-, inter- and above-municipality lines of power involved in implementation. The paper examines how the current construction of circular economy knowledge in planning, or its governamentality, can be used as power; and how indicators to measure performance can generate tensions between central and local tiers of government, underpinning a wider neoliberal ideology. Finally, we reflect on what austerity localism and the politics of scale might mean for the planning and governance of circular economy in cities.
\end{abstract}

Keywords: spatial planning; circular economy; city; governance; England 


\section{Introduction}

Seventy per cent of the world population will live in cities by 2050 (UN, 2014). Cities use $75 \%$ of the world's resources and are responsible for the discharge of waste in similar proportions; they also consume $80 \%$ of the global energy supply (UNEP-DTIE, 2012). It is generally acknowledged that human consumption and production trends cannot be sustained at the current pace without catastrophic consequences for the environment and that, without change, cities will only foster current trends and accelerate resource scarcity and resource insecurity. Hence, cities are currently re-planning themselves and deploying new approaches to face this challenge. Adopting a 'circular economy' (CE thereafter) framework is one such approach.

Cities worldwide, mainly in Europe and the US but also in Asia, are employing CE principles to achieve more resource efficient urban management systems (Ghisellini, Cialani, \& Ulgiati, 2016; Petit-boix \& Leipold, 2018). CE has been driven by governments, policy makers and businesses, as well as organisations such as the Ellen MacArthur Foundation (EMF), a well-known advocator of CE. EMF defines CE as more than recycling and focusing on rebuilding capital, and coins the ReSOLVE framework. ReSOLVE centres on five main characteristics: design out waste; build resilience through diversity; minimise energy use; use renewable energy sources; and think in systems and cascades (EMF, 2013).

Despite being an increasingly popular concept with governments and policy makers, the academic literature on $\mathrm{CE}$ is only emerging. With origins in disciplines as varied as economics, engineering and biology, CE has more recently gained traction within the field of urban studies (i.e. geography, urban management and planning). However, most authors criticise previous conceptualisations and suggest their own. Criticism has emerged along at least three directions which are important for what follows in this paper.

First, most of the understanding is dominated by a business-economic and techno-engineering perspective on $\mathrm{CE}$ at the micro-scale, with little known about its spatial implications and application at the macro-scale of the city (Ghisellini et al., 2016; Prendeville, Cherim, \& Bocken, 2018; Williams, 
2019a). Second, little is known about how CE is implemented at the local level by cities; if CE visions exist at the city level (for example, London, Paris, Amsterdam), it is little clear how CE principles are deployed to smaller urban circumscriptions (Prendeville et al., 2018). Third, the limitations of the CE approach for cities are only discussed by a handful of studies (Prendeville et al., 2018; Williams, 2017, 2019a, 2019b). However and despite mentioning the multitude of stakeholders, its political deficit (Prendeville et al., 2018), and the need for multi-scalar, cross-sectoral frameworks for the management of resources (Williams, 2019a, 2019b), none of these studies engage with the politics and power dynamics of the city, which in turn reflects on CE.

This paper aims to make contributions to these three directions. By focusing on the spatial dimension of $\mathrm{CE}$ and its governance, it is of relevance to an international audience and adds to theory. It complements wider planning debates examining planning's capacity to deliver sustainable development, more generally, and CE, more specifically, and to keep up with rapid urban change; and opens for discussion a new and rapidly emerging space in urban politics, that of circular cities.

The paper also contributes to practice debates from a national/London perspective, which, however, could offer useful lessons to planning practice elsewhere. It examines CE at the macro-scale of the city of London and unpacks local implementation as delivered by its 32 boroughs or municipalities through their London Planning Authorities (LPAs thereafter). The focus on London is timely. London has recently taken significant strides towards the integration of CE principles into spatial planning policy via its 2019 London Plan. In addition, the paper examines the power dynamics that lays at the very heart of London's multilevel governance, a feature of many global cities, and frames planning practice, by looking at both government and governance of planning for CE at the local level. The paper asks two questions, one exploratory and one explanatory:

- What is the government structure for the implementation of CE at the local level in London? and

- How does the governance of London shape the implementation of CE in practice? 
Following from this introduction, the paper develops over six sections. Section 2 engages with conceptualisations of $\mathrm{CE}$ from a planning and governance perspective. It argues that framing $\mathrm{CE}$ through the lens of governing-government-governance in planning would enhance understanding of how $\mathrm{CE}$ is implemented at the urban spatial level. Section 3 presents the research approach and methodology. Section 4 and 5 focus in turn on the government structure and multilevel governance of CE. Section 6 discusses the governmentality of $\mathrm{CE}$ and looks at how planning knowledge for CE is constructed, and the technologies of CE governance. The concluding section reflects on how urban austerity and politics of scale might impact on how CE is planned and governed in cities more widely.

\section{Conceptualising CE, planning and governance}

$\mathrm{CE}$ is an evolving concept with diverse meanings and origins. In a nutshell, CE emphasises the need to transition from a traditional linear 'take-make-dispose' model of production and consumption to a circular model which decouples economic growth from environmental degradation and natural resource consumption (Ness, 2008; Ghisellini, Cialani and Ulgiati, 2016a; Murray et al., 2017). CE has strong roots in resource efficiency and closing material loops thinking (Ayres and Kneese, 1969; Graedel, Allenby and Linhart, 1993; Erkman, 1997). Notably, Boulding (1966) theorised the earth as a closed circular system, which then led to Stahel and Reday (1976) and Frosch and Gallopoulos (1989) to develop the frameworks for loop economics and integrated metabolism, respectively. This has been built upon, more recently, through new concepts such as biomimicry (Benyus, 1997), 'cradle-to-cradle' (McDonough and Braungart, 2009) and the 'blue economy' (Pauli, 2010). CE is understood in this paper as a regenerative process in which (city) inputs and outputs such as land, materials, water, food, energy and waste are minimised and optimised by closing loops.

$\mathrm{CE}$, as applied to an urban context, has only gained interest in the academic community more recently. A particular school of thought seems to emerge around key models such as EMF's ReSOLVE framework and the Dutch Circularity in Urban Regions framework promoted by the AMS Institute in Amsterdam. However, academics outside these schools of thought criticise these models for poor understanding of how CE is actually applied to an urban context. Prendeville and colleagues 
(2018) list a number of limitations of a CE approach to cities including: the focus on the micro-scale of business/product cycles as opposed to the macro-scale of the city; side-lining social, behavioural and lifestyles factors; too focused on waste; a predominantly business-technocentric-economicresource-driven perspective; poor understanding of urban politics and the multitude of urban stakeholders; and scarcity of empirical data and evidence of implementation. Furthermore, Williams (2019a, 2019b) argues that the ReSOLVE framework is inadequate when applied to cities because cities are complex ecosystems; they consume resources and therefore a focus on production only is inadequate; and that land/infrastructure should also be considered as scarce resources. What is more, cities change. They need to be planned 'flexibly' as 'physical' formations, meaning that the scales and locations of CE are key. Williams also acknowledges the challenge of implementation and comments on its multiple facets.

Four important observations emerge from this criticism. First, the studies above acknowledge the gap between CE conceptualisation and implementation, and how little we actually know about how CE is implemented in cities. Implementation is ambiguously understood (Williams, 2019b) and CE is rarely discussed from an urban applicability angle (Lieder \& Rashid, 2016) even when cities self-identify themselves as circular cities (Prendeville et al., 2018). Despite being adopted globally by cities as a narrative for development, only a handful of studies, and mainly in a Chinese context, engage with what that may mean for the city (Zhijun \& Nailing, 2007).

Second and closely related to the implementation gap, three scales at which CE can be implemented have emerged in the literature: micro, meso and macro (Ghisellini et al., 2016; Merli, Preziosi, \& Acampora, 2018; Prieto-sandoval, Jaca, \& Ormazabal, 2018). Micro-level analyses focus on CE within businesses, firms and enterprises (Lewandowski, 2016), meso-level analyses on industrial symbiosis and eco-parks (Park, Sarkis and Wu, 2010) and macro-level analyses on cities, regions and nations (Yuan, Bi and Moriguichi, 2006). Whilst some argue that the different levels, as core principles of CE, are contrasting and contradictory (Prendeville et al., 2018), others maintain that CE is ultimately about transition and closing loops at every level (Deutz and Gibbs, 2008). While the 
micro- and meso-level are relatively well covered in the literature, the macro or city level is less understood.

Third, there is little consensus about how CE can be applied to the complex context of cities. Thinking 'at scale' and 'in physical' terms would enhance this understanding. The current CE agenda mainly targets businesses to emphasis environmental and economic benefits that can be achieved through reduced resource consumption and environmental pollution, with most authors focussing on resource inputs, waste and emissions outputs (Geissdoerfer, Savaget, Bocken, \& Hultink, 2017). Hence, studies employ a techno- and/or business-centric perspective focusing on 'business competitiveness', enhanced by technical design, manufacturing and service redesign and resource flows, centred on processes of reducing resource use, reusing and recycling (D'Amato et al., 2017; Kirchherr, Reike and Hekkert, 2017).

Last and drawing from the above, cities are complex socio-economic, but also political-administrative systems. Williams (2019b) identifies important regulatory, political and institutional challenges to implementing CE and notes the role that multi-scalar organisations play in implementation across CE initiatives, while Prendeville and colleagues (2018) note that the multitude of stakeholders and politics that $\mathrm{CE}$ engages with require urgent attention. Despite these observations, however, $\mathrm{CE}$ debates focus to date on 'people-less' and 'institution-less' natural and mechanical system analogies which allow for disengagement with issues of power (Sahakian, 2016). Hence, it can be argued that CE's lack of focus on city governance processes and power dynamics is a key limitation of CE literature, particularly given its increased utilisation by national governments, cities and organisations around the world (Geissdoerfer et al., 2017; Ghisellini et al., 2016; Moreau, Sahakian, Griethuysen, \& Vuille, 2017).

The following sub-sections aim to bring the 'spatiality' of the built environment and the 'politics' of cities, through the lens of spatial planning, back into CE debates. They discuss in turn the interface between spatial planning and $\mathrm{CE}$, and $\mathrm{CE}$ and city governance, with a view that while the former has been seen as a lever for implementation, the latter holds important lessons for implementation. 


\section{Spatial planning and CE}

Although the importance of planning seems to grow ever smaller, the problems facing planners seem to grow ever larger and more complex. Implementing CE in cities is one of them. There are strong connections between spatial planning (planning thereafter) and CE. Most notably, there are links between CE and sustainable development (Geissdoerfer et al., 2017), with planning being leveraged to lead on the delivery of sustainable development at the city level (Polk, 2010; Rydin, 2011; Turcu, 2018b) or even both (GLA, 2017). Planning deals with how "physical resources of places are used and managed' (Hull, Healey, Madanipour, \& Madani, 2001) to secure the public good (Vigar, Healey, Hull, \& Davoudi, 2000), and represents a political arena where the growth and decline, but also infrastructure and use of resources in cities, are managed, and where decisions about land and infrastructure use are made (Tewdwr-Jones, 2012). This occurs through a multi-scalar multistakeholder process which produces a plan that encompasses a vision of urban change (Rydin, 2010), set within wider economic and political forces embedded in governmental and governance webs (Tewdwr-Jones, 2012). Planning is defined in this paper as a dynamic process where mainly land and infrastructure, but also other urban resources such as energy, water, waste and food, are managed. This is done on the basis of political decisions made about land and other urban resources and in the context of formal regulations and procedures (the structure or government of planning) and networks of stakeholders with different interests and at different levels (the governance of planning).

At least three important themes have emerged in planning over recent decades. These have developed in parallel to the CE concept and are therefore important for its framing: the inclusion of sustainable development as a core principle of planning; the acknowledgement of multi-level networks of stakeholders that shape cities and their planning; and local planning as the main locus for implementation of sustainable development and/or CE.

First, governments and policy makers place planning at the centre of delivering sustainable development (Healey, Shaw, Healey, \& Shaw, 2018; ODPM, 2005; Turcu, 2018a, 2018b). The relationship between sustainable development and CE is complex and their overlap little discussed, with the two terms used interchangeably. For example, some authors question CE's sustainability 
claims, as CE advocates a 'good growth' narrative based on increasing city competitiveness' by 'valorising waste' for 'advantage' and 'value creation' ((Lacy \& Rutqvist, 2016) quoted in (Prendeville et al., 2018)). Nevertheless, the links between sustainable development and circularity are recognised in debates of 'zero-waste cities' (Zaman \& Lehmann, 2013), 'smart cities' as enablers of digitalisation and 'wise management of natural resources' (Neirotti, De Marco, Cagliano, Mangano, \& Scorrano, 2014) and 'sharing cities' as platforms for recycling and sharing resources, goods and services (McLaren \& Agyeman, 2015).

Second, there is an increasing recognition of diverse multi-level networks of stakeholders, and associated power dynamics, involved in planning, especially when sustainable development is concerned (Yvonne Rydin, 2010; Turcu, 2018a). Through its facilitation role which aims to mediate the competing interests of urban stakeholders (Bulkeley, 2006), planning is politically 'charged' while translating knowledge, acting on collective issues and looking into the future in a way that cuts across scales and governance landscapes (Hurlimann \& Wilson, 2018; Turcu, 2018b).

Third, the planning literature highlights the city and, especially, local/ municipal level as foci for the greatest pressures on resources and hence, the environment (Owens \& Cowell, 2010; Preuss, 2007; Turcu, 2018a, 2018b). Cities are important resource consumers and municipalities have extensive local knowledge, and manage most of these resources including land, infrastructure, water, energy and waste. Hence, local/municipal planning is instrumental in addressing land use 'consumption', a point only addressed by a few CE scholars (Geissdoerfer, Savaget, Bocken, \& Hultink, 2017), but also the spatial implications of other urban systems such as infrastructure, waste, energy etc within and beyond the environmental and social contexts of their cities (Wilson \& Piper, 2010).

The complexity of planning cannot be discussed in isolation from contemporary broader societal dynamics - such as the turbulent, and contradictory to the remit of planning, waters of neoliberalism, austerity and transnationality - which have seen new spaces of urban politics emerge. Contemporary debates highlight tensions between planning as the very lever of city management dynamics and the fact that boundaries cannot be imposed on urban politics. This is to say, planning aims to establish a template for spatial (and functional) divisions, or territorialise space, in urban development and 
negotiates both formal and informal rules that guide such development (Ward K. et al. 2018); this 'territorialisation' is at odds with the politics of wider urban processes. For example, the works of David Harvey, Ed Soja and Doreen Massey speak to that, arguing that broad societal processes and power struggles do not occur in space, but rather space helps to 'operationalise' these processes.

\section{Framing CE through a planning governance lens}

The discussion above refers to the multitude of stakeholders involved in the delivery of urban CE and notes that planning can be seen as a lever for implementation. It notes the multi-level stakeholder and political decision-making processes that planning engages with and its tensions with contemporary debates on urban politics. This highlights the importance of understanding how planning is governed. It is here where the governance literature, drawing mainly on political studies with some insights from geography, offers an useful entry point. Three concepts lay at the heart of this literature: governing, government and governance. They are closely interrelated and equally important to discuss.

Governing can broadly be defined as the process, and intended efforts, that 'create the conditions for ordered rule and collective action within the political realm', in order to control, steer or manage society (Kooiman \& Kooiman, 1993; Stoker, 2004). It refers to and includes both the government and governance concepts. Government refers broadly to the structure or institutional arrangement for the governing of an area (Lefèvre, 1998) and is traditionally seen as the main form of governing at local, regional and national level. Government governing means making policy in four hierarchical steps: setting policy objectives (1), which are formulated into policy (2); policy is then implemented (3) and monitored (4) via performance targets and indicators.

More recently, however, it has been argued that a government-centred perspective on governing is not sufficient to understand decision-making in society. Modern conceptualisations of governing diverge from a traditional focus on hierarchical lines of power, to emphasize the formulation and implementation of policy through dynamic lines of power and networks of actors inside and outside the government (Bulkeley \& Kern, 2006). Rawls has famously framed this a moving 'from government to governance' whereby governing takes place as networked governance in the context of 
links between various actors at various levels. Networked governance enacts governing through connections of influence, knowledge, authority and resource-flows up and down, and also across the many connections within these multi-scalar networks (Betsill \& Bulkeley, 2006; Bulkeley \& Betsill, 2005; Eckerberg \& Joas, 2004; Kern \& Bulkeley, 2009a, 2009b). This is reflected in debates of cityregionalism and scalar-politics in geography studies, and multi-level governance (MLG) in political science.

City-regionalism depicts the political convergence of spatial scales which were traditionally separate. It emphasises the role of power within the governance discourse, and it is currently advocated by governments in order to address the distributional and political challenges of uneven development (Jonas \& Moisio, 2018). Scalar-politics, in turn, highlight the relation between scale and power i.e. the scale at which the governance of resources occurs becomes one means to exert power (Swyngedouw \& Heynen, 2003). While these two concepts are concerned with power, MLG is more concerned with the structure of power as framed by pre-determined rules. It recognises, however, that urban policy making links across scale from local to supranational and that power is distributed across horizontal and vertical networks which do not operate in a hierarchical manner (Bulkeley \& Betsill, 2005).

Power is an important concept to both the process of planning and governing and is usefully conceptualised by Lukes' (2004) tripartite model: overt power or 'decision-making' (Dahl, 1957); covert power, also termed 'non-decision-making' (Bachrach \& Baratz, 1962); and latent power or 'power-as-knowledge' (Patton \& Morris, 1979). While the first two are self-explanatory, the latter is grounded in Foucault's work on the power/knowledge nexus or 'le savoir-pourvoir' and forms the basis of governmentality studies. Here, power is based on knowledge, makes use of knowledge, and reproduces knowledge according to its interests (Patton \& Morris, 1979). A governmentality perspective sees knowledge as never neutral because it determines power relations. To further unpack this, governmentality scholars look at how discourses of knowledge are constructed in policy making and how, for example, governmental technologies (such as indicators, reports, charts, tables and maps) are used in the construction of knowledge (Pettenger, 2016). Miller and Rose (1995), for example, look at how governmental technologies construct 'responsibilised' or 'self-governable' 
subjects/actors in order to enable 'governing from a distance' which makes direct governing unnecessary (Rose \& Miller, 1992). In a nutshell, governmentality frames a certain 'mentality' of government which can be defined by 'governing from a distance' through networks of actors.

Despite the complementarity that governance (and power) brings to government (structure) in understanding the wider process of governing, some scholars voice concerns about an almost exclusive focus on governance (and power) in contemporary urban debates. This, they argue, have led to the proliferation of networked governance literature and downplayed the role that governments as the very structure (or lack thereof) of governing still plays in shaping urban processes (Jessop, 2003). In fact, this shift in focus and responsibility from state (government) to networks of non-state and local actors (governance) is a key characteristic of the current 'era of austerity' in England. The English 'austerity localism' manifests as a widespread form of governance whereby it is argued that stakeholders 'from the bottom' know best how to network with next level-up to deliver local needs and govern the 'local', or, in governmentality terms, enable governing 'from a distance' (Lowndes \& Pratchett, 2012)

This paper echoes these concerns and follows others (Jessop, 2003; Yvonne Rydin, 2010) to use a theoretical framework that allows for a holistic exploration of the governing process of CE, by looking at both the government and governance (and power) of planning for CE in London, to map the 'rules' that guide its implementation and unpack the power dynamics, and subsequent 'construction' of knowledge (as power), between the different scales of governance.

The framework is illustrated by Figure 1 and unpacks the planning governing of CE in London as:

- planning government, the structure that upholds implementation at local/municipal level. This is represented by CE related policy formulation, such as municipal documentation, plans, guidance etc, and policy monitoring, such as performance targets and indicators, at London LPA level; and 
- planning governance which shapes CE implementation in practice determined by London's MLG governance framework and represented by lines of power (and knowledge construction):

- within municipalities (LPAs), spear-headed, for example, by internal prioritisation and/or 'silo' thinking;

- between municipalities (LPAs), such as, for example, competition for scarce resources; and

- upwards, between municipalities, the city of London and the national level, determined, for example, by lack of clarity and/or incompatibility between local, city and policy formulation.

Figure1 - Framing CE through a planning governance lens (Source: Author's own)

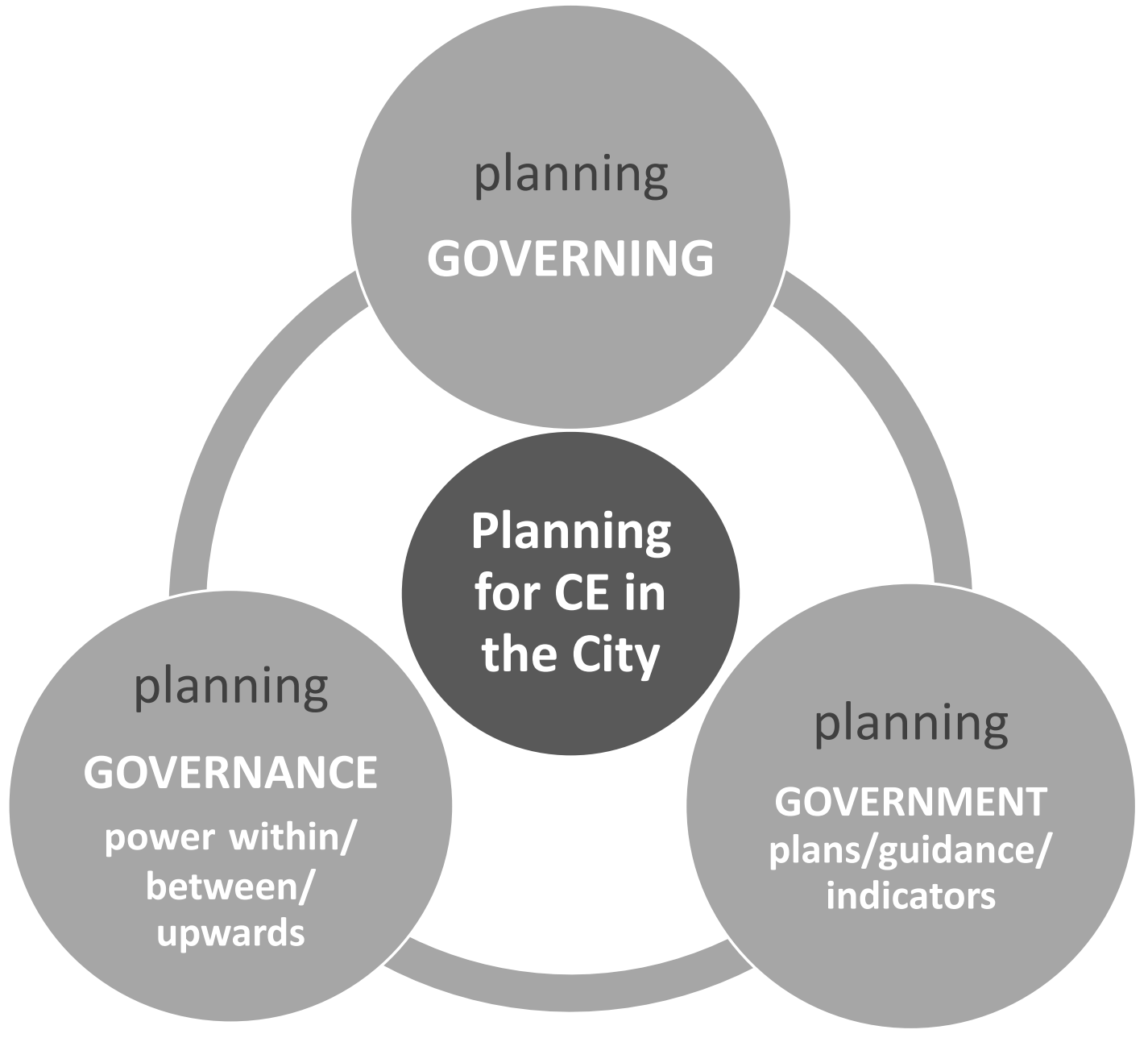




\section{The case of London}

This study is qualitative in approach and draws on one case study, the city of London, with the London boroughs/municipalities and their respective LPAs as multiple units of analysis. The focus on one city allows for more detailed probing not otherwise possible and advocates the importance of local contexts and conditions in yielding deeper insights into complex urban issues (Turcu, 2013; Turcu, Rydin, \& Pilkey, 2014). In addition, both Prendeville at all (2018) and Williams (2019a, 2019b) acknowledge the importance of focusing on one city when CE implementation is concerned as city comparisons can be far-fetched and missing important cultural and contextual factors.

The city of London is an interesting case to investigate for at least four reasons. First, London's planning governance structure is an exception from the rule. It consists of two tiers of government, the city (or metropolitan/regional) tier and local (or municipal/borough) tier (Figure2). At the city level, London is governed by the Greater London Authority (GLA) and a directly elected Mayor (Travers, 2002). At the local level, government is comprised of 32 London boroughs/municipalities and the City of London Corporation; these are classified as 'inner' or 'outer' London, each of them having their own LPAs. With horizontal and vertical networks and lines of power and authority, London is a good example of MLG or networked governance (Rydin, 2010).

Second, London is the only city in England which has a statutory spatial strategy illustrated in the London Plan, produced by its Mayor. The London Plan outlines land use and development strategies across London for a 20-25 year period, and works alongside four other region-wide strategies on environment, transportation, economic development and housing (GLA, 2017). Sustainable development has formed one of the overarching policies of the plan since its first issue in 2004. The latest London Plan was published in 2019 and puts forward six 'good growth' policies, from strong and inclusive communities to increasing efficiency and resilience. With no other planning powers at the city level, the 2019 Plan represents the Mayor's lever to influence local planning whereby borough/municipal local plans have to comply with its content and guidance (Gordon \& Travers, 
2010). Thus, lines of power between planning at the national, city and borough/municipal level shape planning practice in London.

Figure2 - The multilevel planing governance of London (Source: Author's own)

\section{UK Central Government}

Department of Housing, Communities and Local Government

- Produce National Planning Policy Framework (NPPF)

National planning

\section{Greater London Autority (GLA) and Mayor of London}

- Produce the London Plan

- Establish cross-London bodies i.e. London Waste and Recycling Board (LWRB); and inter-borough partnerships i.e. London Legacy Development Corporation (LLDC) and Old Oak and Park Royal Development Corporation (OPDC)

Regional/ London planning

\section{London Boroughs or London Planning Autorities (LPAs) + Corporation of London}

- Produce Local Plans, other plans and spatial guidance (i.e. PPAs and LVLs)

Local/ borough planning

Third, a CE narrative is emerging at the city level in London supported by important policy

developments. CE is the latest policy addition to the 2019Plan and part of its sixth growth policies:

increasing efficiency and resilience (GLA, 2017). Notably, Policy SI7 in the 2019Plan states that 'all planning applications should submit a CE Statement for which further guidance is being produced.'

Moreover, in 2015 the London Waste and Recycling Board (LWARB), a city statutory board that provides direction on strategic waste management, produced a roadmap for London's CE, entitled 'London: The Circular Economy Capital'. The roadmap argues that transitioning to CE can create over 40,000 new jobs in London and bring $£ 7$ billion worth of benefits every year by 2036 (LWARB, 2015b). The roadmap outlines the vision for London's adoption of CE principles under five key waste 
sectors: the built environment, plastics, textiles, food and electricals (LWARB, 2015). It states that London boroughs play a key role in CE transitions due to their powers over 'housing, local plan development and implementation, economic development, waste management and health and wellbeing' (LWARB, 2017) p.10. LWARB further recommends that 'local authorities develop local programmes to support the acceleration of the $C E^{\prime}$, and the built environment section recommends that LPAs should encourage CE in relation to material reuse and design for adaptability (LWARB, 2017:12). LWARB also runs three programmes centred on London's CE: Advance London, Resource London and Circular London (LWARB, 2017).

Finally, London's CE narrative sits within the wider context of CE policy at the national and international level, as well as initiatives in the private sector. In 2018, the national government released 'Our Waste, Our Resources: a Strategy for England', outlining plans for greater resource efficiency, and in particular waste management, and a transition to CE (HMGov, 2018). Such action has been driven by European CE-related policies. In 2015, the European Commission adopted the Circular Economy Action Plan. The plan proposes a variety of actions on production, consumption, waste management, material markets and eco-design, accompanied by timelines and ambitious recycling targets (EC, 2015). Moreover, the European Circular Economy Package was published in 2018, made up of four new EU Directives and requiring Member States to transpose those into national legislation. There are also key international organisations such as the Organisation for Economic Cooperation and Development (OECD, 2019) and World Health Organisation (WHO, 2018) which actively promote CE thinking, and CE aligns well with Sustainable Development Goal 12 (Responsible consumption and production). In addition, many private sector organisations push the CE narrative, guided by profit and efficiency of supply chains, and increasing pressures for social corporate responsability. Examples in the UK include ARUP, with its 'Circular Economy in the Built Environment' vision (Arup, 2016); and Clarion Housing Association, with its Circular Economy Strategy to deliver 12,500 housing units across the Borough of Merton. 


\section{Methods, data collection and analysis}

This is the first study of such scale and scope as we interviewed almost all LPAs in London (88\% coverage). Thus, it is fair to say that our data and subsequent findings are representative for London. In total, 36 semi-structured interviews were carried out during the summer of 2018. These include 28 (out of 32) interviews with LPAs, and 8 with representatives from other relevant organisations such as the London Legacy Development Corporation, Old Oak and Park Royal Development Corporation,

GLA, LWARB and North London Waste Partnership. Interviewees were contacted first via email and then interviewed either over the telephone or in person. They ranged in position from junior (5) through mid (16) to senior (15), and came from a planning (22), sustainability and environment (11), and waste (3) professional backgrounds.

The interviews were instrumental in examining how CE is understood within LPAs and how local planning is responding to and interacting with city and national level CE policies and agendas. The interview questions were broadly structured along five themes: how municipal planning understands, and translates CE in planning practice; what is its role in delivering CE; and whether and how it works towards CE policies outlined in the London Plan and LWARB's Circular Economy Roadmap. The interview data was analysed using Atlas.ti and open coding (Lofland, 2006), followed by focused coding (R. M. Silverman, 2015).

The analysis also draws on authors' secondment with the organisation commissioned by GLA to develop further guidance for its S17 Policy. That meant we were able to have informal discussions with a variety of CE third parties such as the Building Research Establishment, UK's Green Building Council, and various developers, built environment consultants and other policy makers. Two other CE-related events were attended during 2018: an All-Party Parliamentary Sustainable Resource Group meeting and the Environment Services Association's 'Energy for the circular economy: An overview of energy from waste in the UK' event. Despite not being directly drawn upon here, informal discussions and attendance to the two events have enhanced our understanding of the wider context for $\mathrm{CE}$ in London and helped us to triangulate information from the interviews. 


\section{Government for CE: policy formulation and monitoring}

Whilst CE features large in London's narrative, it appears little at the borough/municipal level. Only eight out of 32 boroughs refer to CE in policy formulation. These are the boroughs of Brent, Islington, Westminster, Merton, Tower Hamlets, Southwark, Sutton and Lambeth. Table 1 summarises briefly $\mathrm{CE}$ associations at the local level, relevant policy documents and actors involved in implementation.

Table 1: CE focus, policy formulation and examples of actors involved in implementation in London (Source: Authors' review of municipal policies, October 2019)

\begin{tabular}{|c|c|c|c|}
\hline $\begin{array}{l}\text { London } \\
\text { Borough }\end{array}$ & CE focus & Policy formulation & Actors \\
\hline Brent & $\begin{array}{l}\text { Waste/ low- } \\
\text { carbon }\end{array}$ & $\begin{array}{l}\text { Brent Responsible Growth Strategy } \\
\text { (RGS): Economy 2018-2038 (2018) }\end{array}$ & $\mathrm{n} / \mathrm{a}$ \\
\hline Islington & $\begin{array}{l}\text { Design } \\
\text { Construction } \\
\text { Waste }\end{array}$ & $\begin{array}{l}\text { Islington Local Plan } \\
\text { Policy S10: Circular Economy and } \\
\text { Adaptive Design (2018) }\end{array}$ & $\begin{array}{l}\text { Derwent London; } \\
\text { LWARB }\end{array}$ \\
\hline Westminster & $\begin{array}{l}\text { Recycling } \\
\text { Re-use }\end{array}$ & $\begin{array}{l}\text { Greener City Action Plan 2015-2025 } \\
\text { (revised 2018) }\end{array}$ & Grosvenor Estates \\
\hline Merton & $\begin{array}{l}\text { Waste } \\
\text { Regeneration } \\
\text { Supply chains }\end{array}$ & $\begin{array}{l}\text { Currently working on new Local Plan } \\
\text { 2021-2041(2021) } \\
\text { Clarion Circular Economy Strategy } \\
\text { (2018) }\end{array}$ & $\begin{array}{l}\text { Clarion HA, Loop; } \\
\text { LWARB }\end{array}$ \\
\hline $\begin{array}{l}\text { Tower } \\
\text { Hamlets }\end{array}$ & Waste & $\begin{array}{l}\text { Don't let our future go to waste: Waste } \\
\text { management Strategy 2018-2030 (2018) }\end{array}$ & $\begin{array}{l}\text { LWARB, UrbnRok, } \\
\text { IKEA, First Mile } \\
\text { Action }\end{array}$ \\
\hline Southwark & Waste & New Southwark Plan 2017-2033 (2019) & Veolia \\
\hline Sutton & $\begin{array}{l}\text { Upcycling } \\
\text { Re-use } \\
\text { Sharing } \\
\text { Recycling }\end{array}$ & $\begin{array}{l}\text { Creating a Circular Economy Action } \\
\text { Plan 2019- } 2023 \text { (2019) }\end{array}$ & $\begin{array}{l}\text { South London Waste } \\
\text { Partnership, LWARB, } \\
\text { Thames Water, GLA, } \\
\text { Veolia }\end{array}$ \\
\hline Lambeth & $\begin{array}{l}\text { Waste } \\
\text { Recycling }\end{array}$ & $\begin{array}{l}\text { Municipal Waste Management Strategy } \\
\text { 2011-2031: Policy 7.1.2 (2010) }\end{array}$ & $\mathrm{n} / \mathrm{a}$ \\
\hline
\end{tabular}

The local focus is predominantly on waste and this has resulted in a number of partnerships across borough boundaries such as the South London Waste Planning Authority, a joint initiative of Sutton, Croydon and Kinston boroughs; and the North London Waste Authority, between seven north London boroughs (Barnet, Camden, Enfield, Hackney, Haringey, Islington and Waltham Forest). Two boroughs, Islington and Sutton, seem to take a wider approach. For instance, Islington's Local Plan 
states that 'all developments must adopt a circular economy approach to building design and construction' and emphasises the importance of recovery, reuse, recyclability, flexibility and adaptability (Islington, 2018). Moreover, given London's heightened attention to climate change, with many London boroughs declaring climate emergencies, $\mathrm{CE}$ focus seems to have shifted more recently from waste to carbon mitigation; an example here is borough of Brent's 2018-2038 Responsible Growth Strategy which talks about 'a low carbon circular economy' model (Brent, 2018).

LWARB plays a central role in promoting CE across London. The organisation supports the incorporation of CE into the 2019Plan and works with businesses to encourage and facilitate collaboration for CE. Despite this, however, CE does not feature largely in the private sector narratives, with most of action in London concentrated on recycling hotel mattresses, coffee cups, food and packaging (Circular London 2019). Two initiatives in the built environment stand out at the time of writing: Clarion Housing Group's circular thinking on the regeneration of 12,000 housing units across three sites in the borough of Merton; and the Old Oak and Park Royal Local Plan, a specially designated area of strategic development in London and UK's largest regeneration site, which represents the clearest incorporation of CE into a planning document (ARUP, 2017)

London boroughs through their LPAs have a duty to formulate planning policy such as Local Plans (LPs) and spatial guidance, and monitor performance, in accordance with the National Planning Policy Framework and 2019Plan (see Figure 2). LPs outline 10-15 years local visions for land-use development. In addition, LPAs can produce other spatial planning guidance including Supplementary Planning Guidance (SPGs) to further detail elements of LPs, Planning Performance Agreements (PPAs) to support pre-planning application processes and Local Validation Lists (LVLs) to enlist the information required for planning applications. LPAs progress towards the outputs of LPs is monitored nationally, through a Annual Monitoring Report, and at the London level through the 2019Plan's twenty-four indicators (MoL, 2018b).

LPs in particular were seen by our interviewees as important tools to include CE strategies such as land reuse, adaptability and disassembly. They play an important role in establishing rules and expectations across built environment actors (Rydin, 2010). 
For it [CE] to come into play in decision making in planning it would have to feature quite prominently in LPs used on a day-to-day basis for assessing proposals. It would have to be language that becomes part of the direct planning considerations that are considered and weighed up every time a decision is made...it would need a clear basis in development plan policy (Outer London borough)

Interviewees also talked about the significance of LPs to developers who use them as starting points in their proposals, but also to other municipal departments such as regeneration and development management which refer to them in their work. As Table1 above shows, only two boroughs, Islington and Southwark, had CE written into their LPs in 2019; and one borough, Merton, was updating its LP to incorporate $\mathrm{CE}$ at the time of writing.

The early stages of the planning process were also seen as important for delivering CE in practice:

I would go along to a sustainability meeting with the developers and, maybe, their energy and sustainability consultant, and promote that this [CE] is what we're expecting. We start by talking about it [CE] and encouraging them first and then gradually make it mandatory... The earlier we bring these things up the more likely the developers are to listen to us because they can factor it into their costs (Inner London borough)

The importance of introducing CE into early dialogues with the developers recalls the centrality of viability for both LPAs and developers (Ferm, 2018). To this extent, the Planning Performance Agreements (PPAs) in the pre-application process were mentioned as a practical tool through which this could happen, and enabled LPAs to play a proactive role in 'lobbying' CE at the early stages of the planning process (Pomponi \& Moncaster, 2016).

I think they [PPAs] are incredibly useful for shaping developments. At the pre-application stage planners can be very proactive (Inner London borough)

Where LPAs had no formal guidance on CE, PPAs and pre-application discussions were seen as offering an important opportunity to incorporate or at least start a discussion with developers on CE. This is relevant as PPAs are increasingly seen as important components in the pre-application 
planning process in England, mainly due to the role they play in capturing development value within the context of British austerity (Canelas, 2018). In 2015, PPAs were used in half of major planning applications in England (Kochen, 2016).

LPAs were well aware of the Policy S17 statement on CE introduced by the 2019Plan and saw it as a potential lever to implementing $\mathrm{CE}$ at local level. However, there was little clarity about what it really meant in practice and more detailed guidance from the GLA was expected. Local Validation Lists (LVLs) were also identified as a potential place where CE principles could be introduced in the planning process. LVLs are compiled by municipalities and list the information required for planning applications. They have to align with both national planning policy as well as the London Plan (MHCLG, 2018).

We are just finalising our Local Validation List. Would CE go in there or in another type of statement or assessment, where planning applicants need to demonstrate how they've promoted the CE? (Outer London borough)

Additionally, LPAs considered measuring planning performance to be important, and commented that current monitoring was heavily skewed in favour of housing outputs.

The only most important thing local authorities in London care about is housing delivery. Local authorities have to deliver their housing targets, otherwise they may be stripped of their planning powers (cross-London body)

However, most interviewees were unclear about how the delivery of CE can be measured in planning or more widely, as CE was not clearly defined/understood at the municipal level.

It's difficult to think of some direct indicators on CE as CE is not really defined in our borough. I cannot come up with any. Indicators are important, thoug, because there needs to be something tangible for you to be able to understand the effect of different policy interventions and we know that monitoring is an important element of that (Outer London borough) 
Indeed, the 2019Plan has 24 indicators to monitor performance against six city-wide objectives. Two of these objectives are relevant to CE: Objective 1 (i.e. 'a city that meets the challenges of economic and population growth') and Objective 5 (i.e.'a city that becomes a world leader in improving the environment'). The former, however, mainly focuses on housing delivery with no reference to CE, and the latter presumably measures indicators that are related to CE principles such as the recycling of land and buildings ( 3 indicators) and waste recycling ( 1 indicator) (MoL, 2018a) but with no clear link to CE planning policy

\section{Governance of CE: within, between and upwards 'politics'}

Our interviews uncovered horizontal and vertical lines of authority, which shaped planning for CE in London's practice. They were determined by London's multi-level networked governance and can be classified into: 1. horizontal lines of power within LPAs (intra-borough 'politics') and between LPAs (inter-borough 'politics'); and 2. vertical lines of power between LPAs, the GLA and national government (upward 'politics'). These are discussed in detail below.

\section{Intra-borough 'politics'}

It [CE] ultimately gets side-lined by the bigger strategic local priorities of where you gonna put the housing, the jobs...it's nice to have but it's not in the main dashboard of what politicians are looking at. Local politicians are making the decisions on where the strategic direction of the planning documents goes... The benefits of CE aren't realised instantaneously, they're realised over a long time period. Politics finds it very hard to deal with long time periods. (Outer London borough)

It all comes down to local priorities. If you have 50 priorities you have no priorities. CE is priority no 50 (cross-London body)

Local priorities and internal politics of each borough shape the role that local planning plays in implementing CE in practice. The majority of LPAs did not consider CE a high level priority or to be at the forefront of their policy making. Currently, it is the 2019Plan's housing and affordability targets 
which dominate local planning negotiations, with CE 'at the margins' (Outer London borough). Indeed, a number of London boroughs, particularly in outer areas, have seen their housing targets double or triple in recent years (Geoghagen, 2017). The 2019 Plan outlines a London-wide target of 66,000 homes per year and LPAs could see some of their planning powers revoked if they fail to build enough housing within their boundaries (GLA, 2017; Shehab, 2018). Hence, LPAs saw the push for housing from both the national and city/GLA level as carrying more weight than the CE agenda at the local level. They also pointed to the clash between the different timescales of $\mathrm{CE}$ and local politics and planning. Indeed, Wilson (2007) identifies a 2-5 year time horizon dominating planning practice, in sync with political cycles, while implementing $\mathrm{CE}$ in practice requires longer-term timescales.

Both municipal prioritisation and (political and planning) timeframes at local level raise further issues of power. Local planning decision-making sits ultimately with elected politicians who form local planning committees (Blowers, 1980). It is argued that planning committee powers are exercised in an uneven and inconsistent manner, and are limited to a small group of influential individuals such as senior municipal officers and the planning committee's chair (Kitchen, 1997). Thus, arguably, any final decision-making on CE sits outside planning and with elected councillors. As they are 'accountable' to their electorate, local councillors need public 'buy-in' before lobbying and/or supporting planning policy change. Our interviewees did not feel that was happening in the case of CE. In addition, politicians did not feel they can show accountability (via measurable targets and concrete deliverables) and the public did not have much knowledge about CE.

It's a bit too much to call it a circle of blame but sometimes the officers know that we need to be doing the right thing and we feel frustrated because the residents of our local authority aren't asking for it and so the councillors aren't pushing us to do it (Inner London borough)

Politicians tend to want more simple successes that they can demonstrate and measure...you can't say, yes, we have achieved CE, tick, move on to the next policy objective (Inner London borough) 


\section{Inter-borough 'politics'}

Working with other boroughs, CE is not just a one borough problem. It's across

London ...that [Association of London Borough Planning Officers] is a really good way to get information on what other boroughs are doing to tackle problems (Outer London borough)

Scale is a real thing in CE. The North London Waste Authority, when talking about circularity, it's that level of partnership which will start to unlock things, certainly for local authorities. (Inner London borough)

It does feel tricky within our local authority to look at CE. That's why it's useful to see whole London plans because it's more meaningful on a whole London basis. (Inner London borough)

Working at borough level only and failing to reach out to other municipalities was generally considered a barrier to the delivery of $\mathrm{CE}$ in London. Whilst local translation and relevance were important, LPAs also looked to their neighbours' approaches and across London to draw inspiration and provide CE knowledge. Thus, inter-borough relations and politics were considered important for CE.

The economy of scale needed to deliver aspects of CE, such as material and resource elements, is a challenge which can be minimised through unifying LPAs practice, such as resource management through cross-municipal waste authorities and plans (ESA, 2016). Interviewees also noted that interborough relations were important for learning: forums and groups, like Association of London Borough Planning Officers and the London Environment Directors' Network, enabled learning about CE through sharing ideas, best practices, problems and providing a point of contact for information dissemination by external speakers. Learning is a way in which new goals and changes to the norm can be discussed and is crucial for institutional change (Rydin 2010). Hence, the learning occurring through such multilevel networked governance imperative and presents opportunities for discussing $\mathrm{CE}$, bringing to light how LPAs play a facilitative role as members of the broader London region. 
Learning and inter-borough relations, however, were challenged by austerity measures which reduced resources and capacity: ' 8 years ago we used to work a lot better together. But as our budgets have shrunk we've got a lot more insular' (Inner London borough); and the political geography of London: 'there are different politics across London and some politicians will be more supportive of these [CE] principles than others' (Outer London borough). Notably, a number of interviewees referred to the multilevel governance structure of London as 'fragmented', 'insular looking' and 'watering down the planning system.' In fact, Gordon and Travers (2010) argue that the governance of London is constrained by the complex diversity of the system; the division of powers makes it difficult for overarching Mayoral visions to be implemented because the boroughs represent varied localised interests. This is compounded by the 'territorialisation' of planning which is boundary based and CE working across boundaries.

\section{Upwards 'politics'}

The extent to which London and LPAs can implement CE was seen as also shaped and constrained by national planning policy and the wider austerity agenda. Most LPAs noted that, to implement CE through local planning, the impetus must come from the national level:

CE is one for national government... because if one individual London borough does it, it runs the risk of jeopardising the potential for investment in regeneration and housing.

Developers will go where the market conditions are easiest to work with, if they can go to a local authority that's less demanding...you will end up with fantastic planning policies but very little happening. (Outer London borough)

Interviewees emphasised that national government holds significant planning influence, not only through tools with greater planning powers, such as the National Planning Policy Framework, but also an ability to regulate businesses and developers, to enforce financial (dis)incentives and enact broader behaviour change campaigns.

The English planning system is increasingly being 'marketised', with planning practice depending on growing interdependencies between municipalities and the private sector (Raco, 2018). Indeed, the 
LPAs emphasized the challenges raised by exposure to the market. For example, they thought that implementing CE through planning conditions and regulations could deter developers, who will seek more favourable conditions elsewhere, or cause them to reduce affordable housing numbers on viability grounds. This reinforces the reactive rather than leadership role of LPAs because they depend upon broader politics and powerful actors (Blowers, 1980).

\section{The governmentality of planning for CE}

The analysis above aims to discuss who does what and with what tools (van der Heijden, 2014), whilst capturing the distinct geographies of power (Macleod \& Goodwin, 1999) in planning for the implementation of CE in London.

So, what is the government structure for the implementation of CE at the local level in London?

We identified three main tools that LPAs employ in the delivery of CE in practice: Local Plans (LPs), Planning Performance Agreements (PPAs) and Local Validation Lists (LVLs). However, we found little evidence overall of CE principles being effectively integrated into such planning tools. For example, only three out of the 32 boroughs had 'written' CE into their LPs at the time of writing. Currently LPAs wait for further guidance on Policy S17 in the 2019Plan and national nudging. LPAs find it challenging to define and operationalise $\mathrm{CE}$ in planning practice and lack of monitoring affects both planning and political decision-making in driving CE forward.

How does the governance of London shape the implementation of CE in practice?

We found that planning practice in London is shaped by lines of power at various levels, horizontally and vertically, which, we argue, can help us to understand how $\mathrm{CE}$ is delivered in practice. Internal (intra-borough) local planning dynamics are framed by municipal prioritisation, political timelines and accountability, and public buy-in. In-between (inter-borough) local planning interactions are paramount to CE knowledge translation and learning dissemination, economy of scale thinking, and are negatively influenced by lack of resources and London's complex governance structure. Beyond 
(upwards) local dynamics, planning practice is shaped by the wider reality of English austerity, but also requirements cascading down from the city/GLA and national level.

\section{CE knowledge as power}

CE meaning in local planning terms was much debated across all 28 municipalities interviewed. At one end of the spectrum there was almost complete lack of awareness, but more frequently CE was associated with waste and recycling, and/or aligned with wider sustainability goals. Perhaps this was to be expected, given that the two terms are used interchangeably and overlap (Geissdoerfer et al., 2017).

Local planning plays a central role in constructing knowledge by 'translating' CE principles into something workable within their localities (Owens and Cowell, 2010), such as LPs, PPAs and LVLs. Translation is a powerful planning tool (Campbell, 1996) which makes possible the use of knowledge in various contexts and by various users (Rydin et al., 2007) i.e. translated (or locally constructed) knowledge is used by developers and other urban actors, whilst it brokers relations and communicates knowledge within wider local government and across the built environment (Stone \& Maxwell, 2005).

However, Foucault notes that power is using knowledge with its anonymous intentions and to its own ends (Foucault, 1991). The creation of knowledge is an example of the latent face of power (Lukes, 2004) and operates through 'capillary' action through 'vessels' between governance structures (Foucault, 1991). This means that knowledge is never neutral and reproduces power relations, which raises questions about how $\mathrm{CE}$ knowledge is currently translated into current planning policy at the local, city and national level, for whose interests, to what ends, and what power relations is reproducing. This is particularly important to understand, especially in relation to the 2019Plan which is working on 'operationalising' further its S17 Policy as we speak.

\section{Technologies of CE governance}

The current lack of CE-related performance monitoring such as indicators was a recurring theme throughout our interviews. Interviewees felt that this is a serious barrier in convincing politicians and so, in making CE happen. Lack of CE monitoring is not problematic in planning only, and it is 
reported in other areas of CE implementation (see for example Geng et al., 2012; Di Maio et al., 2017). Planning is an evidence-based process and municipalities must deliver fully evidenced LPs (Nadin, 2007) and require substantial analysis to support their spatial strategies (Healy, 2002;

Davoudi, 2006; Lord and Hincks, 2010). LPAs called for such evidence and indicators to be produced at the city/GLA and national level.

From a governmentality perspective, indicators are governmental technologies which are 'deployed' for two main reasons: to define the 'object' of government (Murdoch, 2004) and 'control' from 'a distance' the process of governing in itself via monitoring and surveillance (Appadurai, 2001). They usually involve some calculation and standardisation to compare performance over time and/or space thus, making subjects visible and enacting government (Rose, 1996).

A number of scholars unpack the role of indicators as governmental technologies in policy making. Rydin (2007) notes that indicators tell an important story about the nature of power relations between national and local levels of government i.e. national government technologies tend to dominate over local government technologies, which can fuel 'resistance' at the bottom. Indicators can also reinforce a form of eco/green-governmentality within the broader context of capitalism to render people and the environment 'governable'(Goldman, 2001; Watts, 2002). Following from this one could argue that local government's demand of CE indicators 'from the top' to 'account' for action 'at the bottom' could result in tensions and subsequently impact negatively on CE implementation. Moreover, governing 'at a distance' via monitoring can become a convenient mantra for England's current austerity localism, whereby 'responsibilised' and indirectly governed local government needs fewer resources than when directly governed and irrespectively of broader structural conditions.

\section{In conclusion: austerity and politics of scale}

In recent years, English planning is shifting under the national government's austerity agenda, towards a deregulated, market-led and devolved framework (Ferm and Tomaney, 2018). Local government undergoes substantial budget cuts with concomitant dispersal of power to the public through the localism agenda and outsourcing capacity to the private sector (Raco, 2018; Rydin \& 
Turcu, 2019; Turcu, 2018b). The extent to which municipalities can implement CE in London is determined by the wider reality of English austerity, which interferes with the translation and operationalisation of $\mathrm{CE}$ in planning practice.

Municipalities described this 'era of austerity' as planning departments being 'strapped for cash' and lacking 'officers who would be able to work' on CE. Between 2010 and 2016, spending on development and local planning services reduced by over 50\% in England (Raco, 2018) and the number of planning staff decreased by an average of $37 \%$ (Ferm \& Tomaney, 2018). Municipalities reported fewer team meetings and severely reduced capacity for gathering evidence. This impacts communication and learning in local planning, vital for developing new knowledge and defining new agendas such as CE (Bulkeley, 2006; Rydin, 2010).

The squeeze on finances occurs in a context of increasing planning requirements (Clifford, 2018) which limits local planning ability to show leadership by focusing on 'balancing the books' as a priority. Hence, current planning decisions in London is low-risk, cost-efficient and fast-paced, often characterised by path dependencies (McLean and Borén, 2015). Austerity consequences are intertwined with heighted local responsibility through the Localism agenda which aims to selfresponsibilise local government and communities, however, without a concomitant shift in resources, power or authority (Davoudi \& Madanipour, 2013).

The points raised above recall broader contemporary shifts towards a 'withdrawal of the state' in favour of deregularisation and decentralisation. The latter is particularly relevant to planning in relation to debates of scalar-politics and city-regionalism, mentioned earlier in this paper. Scalarpolitics discuss the relationship between power and scale and are especially useful when looking at the use of urban resources from an environmental justice perspective (Swyngedouw \& Heynen, 2003). How resources are governed across scales is of concerned to both planning and CE and can be problematic in a decentralised governing system. That is to say, cities can be planned and/or governed around resource flows at one scale, despite resources being accessed/ distributed/ consumed at another scale. This can create injustices from a spatial development and territorial cohesion perspective (Lawhon \& Patel, 2013). City-regionalism is seen as one means to address such uneven development 
and flows of resources (Jonas \& Moisio, 2018) and lobbied, more recently, as a promoter, facilitator and enabler of CE (OECD, 2019). However, city-regions are not easy to plan due to their contested physical boundaries (Lawhon \& Patel, 2013), or to understand politically as they tend to emerge alongside already existing tiers of governance (Harrison, 2012).

To sum up, the contribution of this paper in further understanding CE in the city is twofold. Theorywise, it conceptualises spatial and political dimensions of CE and opens-up a new space in contemporary urban politics debates, that of urban circularity, by signposting potential tensions with scalar-politics and city-regionalism. Practice-wise, it grounds such dimensions in the planning governance of London by mapping both governing structures and power dynamics of implementation. Lessons from London show cities elsewhere how CE is governed in planning and how CE might change the way we plan and govern the city of the future. 


\section{References}

(Ayres \& Kneese, 1969; Benyus, 1997b; Boulding, 1966; Erkman, 1997; Frosch \& Gallopoulos, 1989; Graedel, Allenby, \& Linhart, 1993; Ness, 2008; Stahel \& Reday-Mulvey, 1981)

(Benyus, 1997a; D'Amato et al., 2017; Deutz \& Gibbs, 2008; Kirchherr, Reike, \& Hekkert, 2017; Lewandowski, 2016; McDonough \& Braungart, 2010; Park, Sarkis, \& Wu, 2010; Pauli, 2010; Sahakian, 2016; Turcu, 2018b; Yuan, Bi, \& Moriguichi, 2006) (Jessop, 2003; Lefèvre, 1998; Rose \& Miller, 1992; D. Silverman, 2019; Ward, Smith, Foy, House, \& Hamer, 2010)

(Campbell, 1996; Canelas, 2018; Clifford, 2018; Davoudi, 2006; Di Maio, Rem, Baldé, \& Polder, 2017; Ferm, 2018; Geng, Fu, Sarkis, \& Xue, 2012; Kooiman \& Kooiman, 1993; Lofland, 2006; Lord \& Hincks, 2010; LWARB, 2015a; McLean \& Borén, 2015; Raco, 2018; Y Rydin, 2010; Rydin et al., 2007; Wilson, 2007)

Appadurai, A. (2001). Deep democracy: urban governmentality and the horizon of politics. Environment and urbanization, 13(2), 23-43.

ARUP. (2017). Circular and Sharing Economy Scoping Study for Old Oak and Park Royal.

Ayres, R. U., \& Kneese, A. V. (1969). Production, consumption, and externalities. The American Economic Review, 59(3), 282-297.

Bachrach, P., \& Baratz, M. S. (1962). Two faces of power. American political science review, 56(4), 947-952.

Benyus, J. M. (1997a). Biomimicry: Innovation inspired by nature. New York: Morrow New York.

Biomimicry: Innovation inspired by nature, Morrow New York (1997b).

Betsill, M. M., \& Bulkeley, H. (2006). Cities and the multilevel governance of global climate change. Global Governance: A Review of Multilateralism and International Organizations, 12(2), 141-159.

Blowers, A. (1980). The limits of power : the politics of local planning policy.

Boulding, K. E. (1966). The economics of the coming spaceship earth. Environmental Quality in A Growing Economy: Essays from the Sixth RFF Forum, 3, 1-20. doi: 10.4324/9781315064147

Brent. (2018). Brent Responsible Growth Strategy (RGS): Economy 2018-2038.

Bulkeley, H. (2006). A changing climate for spatial planning. Planning theory and practice, 7, 203213. doi: $10.1080 / 14649350600673153$

Bulkeley, H., \& Betsill, M. (2005). Rethinking Sustainable Cities: Multilevel Governance and the 'Urban' Politics of Climate Change. Environmental Politics, 14, 42-63. doi: $10.1080 / 0964401042000310178$

Bulkeley, H., \& Kern, K. (2006). Local Government and the Governing of Climate Change in Germany and the UK. Urban Studies, 43, 2237-2259. doi: 10.1080/00420980600936491

Campbell, S. (1996). Green cities, growing cities, just cities?: Urban planning and the contradictions of sustainable development. Journal of the American Planning Association, 62(3), 296-312.

Canelas, P. (2018). Development Value Capture. In J. Ferm \& J. Tomaney (Eds.), Planning Practice: Critical Perspectives from the UK (pp. 70-84).

Clifford, B. (2018). Contemporary challenges in development management. In J. Ferm \& J. Tomaney (Eds.), Planning Practice: Critical Perspectives from the UK (pp. 55-69): Routledge.

D'Amato, D., Droste, N., Allen, B., Kettunen, M., Lähtinen, K., Korhonen, J., . . . Toppinen, A. (2017). Green, circular, bio economy: A comparative analysis of sustainability avenues. Journal of Cleaner Production, 168, 716-734.

Dahl, R. A. (1957). The concept of power. Behavioral science, 2(3), 201-215.

Davoudi, S. (2006). Evidence-based planning: rhetoric and reality. disP-The Planning Review, 42(165), 14-24. 
Davoudi, S., \& Madanipour, A. (2013). Localism and neo-liberal governmentalit. Town Planning Review, 84, 551-562. doi: 10.3828/tpr.2013.29

Deutz, P., \& Gibbs, D. (2008). Industrial ecology and regional development: eco-industrial development as cluster policy. Regional Studies, 42(10), 1313-1328.

Di Maio, F., Rem, P. C., Baldé, K., \& Polder, M. (2017). Measuring resource efficiency and circular economy: A market value approach. Resources, Conservation and Recycling, 122, 163-171.

EC. (2015). Circular Economy Action Plan. Brussells: European Commission.

Eckerberg, K., \& Joas, M. (2004). Multi-level Environmental Governance: a concept under stress? Local Environment, 9(5), 405-412.

EMF. (2013). Towards the Circular Economy. Ellen MacArthur Foundation, 1, 1-96. doi: $10.1162 / 108819806775545321$

Erkman, S. (1997). Industrial ecology: An historical view. Journal of Cleaner Production, 5, 1-10. doi: 10.1016/S0959-6526(97)00003-6

ESA. (2016). RESOURCEFUL : UK resource economy.

Ferm, J. (2018). Plan-Making: Changing contexts, challenges and drivers. In J. Ferm \& J. Tomaney (Eds.), Planning Practice: Critical Perspectives from the UK (pp. 39-54): Routledge.

Ferm, J., \& Tomaney, J. (2018). Planning practice : critical perspectives from the UK.

Foucault, M. (1991). The Foucault effect: Studies in governmentality: University of Chicago Press.

Frosch, R. A., \& Gallopoulos, N. E. (1989). Strategies for manufacturing. Scientific American, 261(3), 144-152.

Geissdoerfer, M., Savaget, P., Bocken, N. M. P., \& Hultink, E. J. (2017). The Circular Economy - A new sustainability paradigm? Journal of Cleaner Production, 143, 757-768. doi: 10.1016/j.jclepro.2016.12.048

Geng, Y., Fu, J., Sarkis, J., \& Xue, B. (2012). Towards a national circular economy indicator system in China: an evaluation and critical analysis. Journal of Cleaner Production, 23, 216-224. doi: https://doi.org/10.1016/j.jclepro.2011.07.005

Geoghagen, J. (2017). Housing - What the mayor 's new housing targets mean for London boroughs. Planning: London, 8, 2-4.

Ghisellini, P., Cialani, C., \& Ulgiati, S. (2016). A review on circular economy: The expected transition to a balanced interplay of environmental and economic systems. Journal of Cleaner Production, 114, 11-32. doi: 10.1016/j.jclepro.2015.09.007

GLA. (2017). The London Plan: The spatial development strategy for greater London. Draft for public consultation.

Goldman, M. (2001). Constructing an environmental state: eco-governmentality and other transnational practices of a 'green'World Bank. Social problems, 48(4), 499-523.

Gordon, I. R., \& Travers, T. (2010). London: Planning the ungovernable city. City, Culture and Society, 1, 49-55. doi: 10.1016/j.ccs.2010.08.005

Graedel, T. E., Allenby, B. R., \& Linhart, P. B. (1993). Implementing industrial ecology. Technology and Society Magazine, IEEE, 12, 18-26. doi: 10.1109/44.192717

Harrison, J. (2012). Life after regions? The evolution of city-regionalism in England. Regional Studies, 46(9), 1243-1259.

Healey, P., Shaw, T., Healey, P., \& Shaw, T. (2018). Changing Meanings of ' Environment ' in the British Planning System Changing meanings of ' environment ' in the British planning system. $19,425-438$.

HMGov. (2018). Our Waste, Our Resources: a Strategy for England. London: Her Majesty Government.

Hull, A., Healey, P., Madanipour, A., \& Madani, A. (2001). The governance of place : space and planning processes / edited by Ali Madanipour, Angela Hull and Patsy Healey.

Hurlimann, A., \& Wilson, E. (2018). Sustainable Urban Water Management under a Changing Climate: The Role of Spatial Planning. Water, 10, 546. doi: 10.3390/w10050546

Islington. (2018). Islington London Plan.

Jessop, B. (2003). Governance and meta-governance: on reflexivity, requisite variety and requisite irony. In H. Bang (Ed.), Governance as Social and Political Communication. Manchester: Manchester University Press. 
Jonas, A. E., \& Moisio, S. (2018). City regionalism as geopolitical processes: A new framework for analysis. Progress in Human Geography, 42(3), 350-370.

Kern, K., \& Bulkeley, H. (2009a). Cities, Europeanization and multi-level governance: governing climate change through transnational municipal networks. JCMS: Journal of Common Market Studies, 47(2), 309-332.

Kern, K., \& Bulkeley, H. (2009b). Governing climate change through transnational ( governance ) networks. Jcms, 47, 309-332.

Kirchherr, J., Reike, D., \& Hekkert, M. (2017). Conceptualizing the circular economy: An analysis of 114 definitions. Resources, Conservation and Recycling, 127, 221-232.

Kitchen, T. (1997). People, politics, policies and plans : the city planning process in contemporary Britain<span class="frbrsuppress" $>/ \&$ nbsp.

Kochen, B. (2016). How performance agreements are driving change in local authority planning departments. Planning Resource.

Kooiman, J., \& Kooiman, J. (1993). Modern governance : new government-society interactions / edited by Jan Kooiman.

Lacy, P., \& Rutqvist, J. (2016). Waste to wealth: The circular economy advantage: Springer.

Lawhon, M., \& Patel, Z. (2013). Scalar politics and local sustainability: rethinking governance and justice in an era of political and environmental change. Environment and Planning $C$ : Government and Policy, 31(6), 1048-1062.

Lefèvre, C. (1998). Gouvernements métropolitains et gouvernance dans les pays occidentaux. Politiques et management public, 16(1), 35-59.

Lewandowski, M. (2016). Designing the Business Models for Circular Economy-Towards the Conceptual Framework. Sustainability, 8, 43. doi: 10.3390/su8010043

Lieder, M., \& Rashid, A. (2016). Towards circular economy implementation: a comprehensive review in context of manufacturing industry. Journal of Cleaner Production, 115, 36-51.

Lofland, J. (2006). Analyzing social settings : a guide to qualitative observation and analysis / John Lofland ... [et al.]. In J. Lofland (Ed.), (4th ed. ed.). Southbank, Vic. : Southbank, Vic. .

Lord, A., \& Hincks, S. (2010). Making plans: The role of evidence in England's reformed spatial planning system. Planning Practice and Research, 25, 477-496. doi: 10.1080/02697459.2010.511019

Lowndes, V., \& Pratchett, L. (2012). Local Governance under the Coalition Government: Austerity, Localism and the 'Big Society'. Local Government Studies, 38, 21-40. doi: 10.1080/03003930.2011.642949

Lukes, S. (2004). Power: A radical view: Macmillan International Higher Education.

LWARB. (2015a). London the Circular Economy Capital: Towards a Circular Economy-Context and Opportunities. London, UK: London Waste and Recycling Board London (LWRBL).

LWARB. (2015b). London: The Circular Economy Capital.

LWARB. (2017). London's Circular Economy Route Map: Executive Summary. 12.

Macleod, G., \& Goodwin, M. (1999). Space, scale and state strategy: rethinking urban and regional governance. Progress in Human Geography, 23, 503-527. doi: $10.1191 / 030913299669861026$

McDonough, W., \& Braungart, M. (2010). Cradle to cradle: Remaking the way we make things: North point press.

McLaren, D., \& Agyeman, J. (2015). Sharing cities: a case for truly smart and sustainable cities: Mit Press.

McLean, B. L., \& Borén, T. (2015). Barriers to implementing sustainability locally: A case study of policy immobilities. Local Environment, 20(12), 1489-1506.

Merli, R., Preziosi, M., \& Acampora, A. (2018). How do scholars approach the circular economy ? A systematic literature review. Journal of Cleaner Production, 178, 703-722. doi: 10.1016/j.jclepro.2017.12.112

MHCLG. (2018). Making an application: Supports effective delivery of planning application process.

MoL. (2018a). London Plan Annual Monitoring Report 14. London: Mayor of London (MoL).

MoL. (2018b). LONDON PLAN ANNUAL MONITORING REPORT 14 2016/17. London: Mayor of London (MoL). 
Moreau, V., Sahakian, M., Griethuysen, P. v., \& Vuille, F. (2017). Coming Full Circle Why Social and Institutional Dimensions Matter for the circular economy., 21, 497-506. doi: $10.1111 /$ jiec. 12598

Murdoch, J. (2004). Putting discourse in its place: planning, sustainability and the urban capacity study. Area, 36(1), 50-58.

Nadin, V. (2007). The emergence of the spatial planning approach in England. Planning Practice and Research, 22, 43-62. doi: 10.1080/02697450701455934

Neirotti, P., De Marco, A., Cagliano, A. C., Mangano, G., \& Scorrano, F. (2014). Current trends in Smart City initiatives: Some stylised facts. Cities, 38, 25-36.

Ness, D. (2008). Sustainable urban infrastructure in China: Towards a Factor 10 improvement in resource productivity through integrated infrastructure systems. International Journal of Sustainable Development \& World Ecology, 15, 288-301. doi: 10.3843/SusDev.15.4:2a

ODPM. (2005). Planning Policy Statement 1:. Planning Policy Statement 1: Delivering Sustainable Development.

OECD. (2019). The Circular Economy in Cities and Regions. Paris: OECD.

Owens, S. E., \& Cowell, R. (2010). Land and limits : interpreting sustainability in the planning process.

Park, J., Sarkis, J., \& Wu, Z. (2010). Creating integrated business and environmental value within the context of China's circular economy and ecological modernization. Journal of Cleaner Production, 18(15), 1494-1501.

Patton, P., \& Morris, M. (1979). Michel Foucault: power, truth, strategy: Feral Publications Sydney.

Pauli, G. A. (2010). The blue economy: 10 years, 100 innovations, 100 million jobs: Paradigm publications.

Petit-boix, A., \& Leipold, S. (2018). Circular economy in cities : Reviewing how environmental research aligns with local practices. Journal of Cleaner Production, 195, 1270-1281. doi: 10.1016/j.jclepro.2018.05.281

Pettenger, M. E. (2016). The social construction of climate change: Power, knowledge, norms, discourses: Routledge.

Polk, M. (2010). Sustainability in Practice: The Interpretation of Sustainable Development in a Regional Planning Arena for Dialogue and Learning in Western Sweden. Planning Theory \& Practice, 11(4), 481-497. doi: 10.1080/14649357.2010.525363

Pomponi, F., \& Moncaster, A. (2016). Circular Economy Research in the Built Environment: A Theoretical Contribution. International Conference of Sustainable Ecological Engineering Design for Society.

Prendeville, S., Cherim, E., \& Bocken, N. (2018). Circular cities: mapping six cities in transition. Environmental innovation and societal transitions, 26, 171-194.

Preuss, L. (2007). Buying into our Future : Sustainability Initiatives. 365, 354-365.

Prieto-sandoval, V., Jaca, C., \& Ormazabal, M. (2018). Towards a consensus on the circular economy. Journal of Cleaner Production, 179, 605-615. doi: 10.1016/j.jclepro.2017.12.224

Raco, M. (2018). Marketisation of Planning. In J. Ferm \& J. Tomaney (Eds.), Planning Practice: Critical Perspectives from the UK (pp. 123-137): Routledge.

Rose, N., \& Miller, P. (1992). Political power beyond the state: Problematics of government. British journal of sociology, 173-205.

Rydin, Y. (2010). Governing for sustainable urban development.

Rydin, Y. (2010). Governing for sustainable urban development Earthscan. London. Washington.

Rydin, Y. (2011). The purpose of planning: Creating sustainable towns and cities: Policy Press.

Rydin, Y., Amjad, U., Whitaker, M., Rydin, Y., Amjad, U., \& Whitaker, M. (2007). Environmentally Sustainable Construction : Knowledge and Learning in London Planning Departments. 9357. doi: $10.1080 / 14649350701514686$

Rydin, Y., \& Turcu, C. (2019). Revisiting urban energy initiatives in the UK: Declining local capacity in a shifting policy context. Energy Policy, 129, 653-660.

Sahakian, M. (2016). The social and solidarity economy: Why is it relevant to industrial ecology? In R.Cliftand; \& A.Druckman; (Eds.), Taking stock of industrial ecology (pp. 205-227). New York: Springer. 
Shehab, K. (2018). Councils must meet house-building targets or lose planning powers, Government says. Independent.

Silverman, D. (2019). Interpreting qualitative data. London: SAGE Publications Limited.

Analysing Qualitative Data 140-156 (New York ; London : Routledge 2015).

Stahel, W. R., \& Reday-Mulvey, G. (1981). Jobs for tomorrow: the potential for substituting manpower for energy.

Stoker, G. (2004). Transforming local governance : from Thatcherism to New Labour<span class="frbrsuppress" $>/ \&$ nbsp.

Stone, D., \& Maxwell, S. (2005). Global knowledge networks and international development : bridges across boundaries.

Swyngedouw, E., \& Heynen, N. C. (2003). Urban political ecology, justice and the politics of scale. Antipode, 35(5), 898-918.

Tewdwr-Jones, M. (2012). Spatial planning and governance : understanding UK planning<span class $=$ "frbrsuppress" $>/ \&$ nbsp.

Travers, T. (2002). Decentralization London-style: The GLA and London governance. Regional Studies, 36, 779-788. doi: 10.1080/0034340022000006097

Turcu, C. (2013). Re-thinking sustainability indicators: local perspectives of urban sustainability. Journal of Environmental Planning and Management, 56(5), 695-719. doi: 10.1080/09640568.2012.698984

Turcu, C. (2018a). Responsibility for Sustainable Development in Europe : What Does It Mean for Planning Theory and Practice? Responsibility for Sustainable Development in Europe : What Does It Mean for Planning Theory and Practice? PLANNING THEORY \& PRACTICE, 00, 120. doi: 10.1080/14649357.2018.1478116

Turcu, C. (2018b). Sustainable Development and Planning. In J. Ferm \& J. Tomaney (Eds.), Planning Practice: Critical Perspectives from the UK (pp. 129-202): Routledge.

Turcu, C., Rydin, Y., \& Pilkey, B. (2014). Energy in the locality: a case for local understanding and action. Local Environment, 19(5), 469-478. doi: 10.1080/13549839.2014.921388

van der Heijden, J. (2014). Governance for urban sustainability and resilience : responding to climate change and the relevance of the built environment.

Vigar, G., Healey, P., Hull, A., \& Davoudi, S. (2000). Planning, governance and spatial strategy in Britain : an institutionalist analysis.

Ward, V., Smith, S., Foy, R., House, A., \& Hamer, S. (2010). Planning for knowledge translation: a researcher's guide. Evidence \& Policy: A Journal of Research, Debate and Practice, 6(4), $527-541$.

Watts, M. (2002). Preface: Green capitalism, green governmentality: Sage Publications Thousand Oaks.

WHO. (2018). Circular economy and health: opportunities and risks. Copenhahgen: WHO.

Williams, J. (2017). Circular cities: strategies, challenges and knowledge gaps c. 1-44.

Williams, J. (2019a). Circular cities. Urban Studies, 0042098018806133.

Williams, J. (2019b). Circular Cities: Challenges to Implementing Looping Actions. Sustainability, $11(2), 423$.

Wilson, E. (2007). Adapting to Climate Change at the Local Level : The Spatial Planning Response. Local Environment, 11, 609-625. doi: 10.1080/13549830600853635

Wilson, E., \& Piper, J. (2010). Spatial planning and climate change.

Yuan, Z., Bi, J., \& Moriguichi, Y. (2006). The circular economy: A new development strategy in China. Journal of Industrial Ecology, 10(1-2), 4-8.

Zaman, A. U., \& Lehmann, S. (2013). The zero waste index: a performance measurement tool for waste management systems in a 'zero waste city'. Journal of Cleaner Production, 50, 123132.

Zhijun, F., \& Nailing, Y. (2007). Putting a circular economy into practice in China. Sustainability Science, 2, 95-101. doi: 10.1007/s11625-006-0018-1 